\title{
Transcatheter aortic valve implantation - role of the scrub nurse and radiology technician
}

\author{
Morena Kvaternik*, \\ Pavica Stanišić, \\ Marijan Krpan \\ University of Rijeka School \\ of Medicine, University \\ Hospital Centre Rijeka, \\ Rijeka, Croatia
}

KEYWORDS: transcatheter aortic valve implantation, intervention, nurse, radiology technician. CITATION: Cardiol Croat. 2016;11(3-4):134. | DoI: http://dx.doi.org/10.15836/ccar2016.134

*ADDRESS FOR CORRESPONDENCE: Morena Kvaternik, Klinički bolnički centar Rijeka, Krešimirova 42, HR-51000 Rijeka, Croatia. / Phone: +385-91-734-9766 / E-mail: morena.1207@gmail.com

ORCID: Morena Kvaternik, http://orcid.org/0000-0001-8510-1633 • Pavica Stanišić, http://orcid.org/0000-0003-4460-4888 Marijan Krpan, http://orcid.org/0000-0003-2672-0746

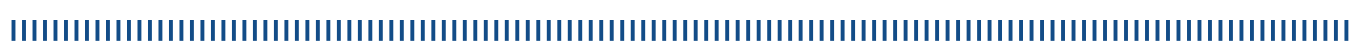

Transcatheter aortic valve implantation (TAVI) is a method in which biologic aortic prosthesis is implanted in stenotic aortic valve. Procedure is indicated in patients with severe, symptomatic aortic stenosis, with severely impaired quality of life and shortened life expectancy which have high perioperative risk and therefore are not suitable for surgical valve replacement. Typical patient is an older person with one or more concomitant conditions or diseases which significantly elevate surgical risk. Nurses or radiology technicians can be assistants in this procedure. They are important members of TAVI team and their role is very significant and they are irreplaceable during the whole procedure. Alongside experience acquired working in cardiac catheterization laboratory it is necessary to carry out additional education for these kind of interventions..$^{1-3}$
RECEIVED:

February 10, 2016

ACCEPTED:

February 20, 2016

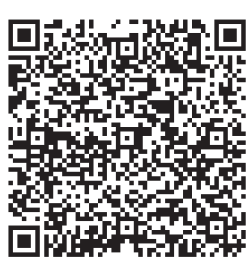

$\square$ Cardiologia Croatica 2016:11(3-4):134.

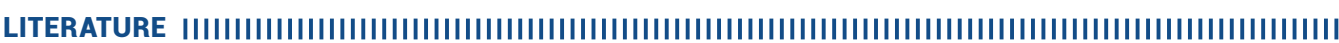

1. MCRae ME, Rodger M. Transcatheter aortic valve implantation outcomes: implications for practice. J Cardiovasc Nurs. 2012;27(3):270-82. DOI: http://dx.doi.org/10.1097/JCN.0b013e318217d288

2. Messing JA. Transcatheter aortic valve implantation. J Cardiovasc Nurs. 2012;27(4):356-64. DOI: http://dx.doi.org/10.1097/JCN.0b013e31822275a8

3. Panos AM, George EL. Transcatheter aortic valve implantation options for treating severe aortic stenosis in the elderly: the nurse's role in postoperative monitoring and treatment. Dimens Crit Care Nurs. 2014;33(2):49-56. DOI: http://dx.doi.org/10.1097/DCC.0000000000000023 